\title{
Kawin Lari from a Modern Perspective: The Representation of Lombok in the Novel Bisikan Tetesan Hujan
}

\author{
Dharma Satrya HD ${ }^{1}$, Faruk $^{2}$, Pujiharto ${ }^{3}$ \\ \{dharmasatrya@mail.ugm.ac.id\} \\ ${ }^{1}$ Universitas Hamzanwadi, ${ }^{2,3}$ Universits Gadjah Mada
}

\begin{abstract}
The background of this article is the centrality of eloping in the culture of Sasak Lombok. That centrality then forces novelists from there to raise the issue of Sasak eloping in Indonesian literature. This article discusses the representation of kawin lari (elopement) in Johan Mahyudi's novel Bisikan Tetesan Hujan. It seeks to explain the position of kawin lari, as a tradition of Lombok's Sasak people, within Indonesian literary discourse. This article thus applies Stuart Hall's theory of representation, combining semiotic and discursive approaches. Data from the novel were analyzed using semiotics, with discourse analysis being used to position kawin lari within its cultural context. Kawin lari is presented in the novel from a modern perspective, being positioned as a tradition that shackles and encumbers women - and therefore victimizes them. Salwa, a victim of kawin lari, attempts to leave her husband, Wawan, in order to pursue her true love. This novel thus offers a construction of Sasak women who are capable of challenging and even rejecting tradition. Despite turning to magical means, Wawan fails to convince Salwa to return to him; the magical is subjugated by the realist and the modern.
\end{abstract}

Keywords: Kawin lari, Sasak, novel, discourse, modernity

\section{Introduction}

The Sasak people's tradition of kawin lari (elopement) has been made an icon of Lombok culture by the government of West Nusa Tenggara. Through the Department of Education and Culture, the provincial government has identified kawin lari as a cultural tradition that should be preserved and protected. In this context, it has included discussion of kawin lari in its publications and identified kawin lari as a uniquely Sasak tradition [1], [2].

Understandings of kawin lari have varied under different regimes. From the colonial era through the New Order, kawin lari was understood from the perspective of a nobilitydominated government. More recently, between 2003 and 2008 West Nusa Tenggara was led by a man of noble heritage, while between 2008 and 2018 it was led by a tuan guru (religious leader); the first group has been identified by orientalists as wetu telu ('three times', i.e. nonOrthodox Muslims), while the latter have been identified as wetu lima ('five times', i.e. Orthodox Muslims) [3], [4]. The practice of eloping becomes an interesting phenomenon for 
anthropologist [5]-[7]. The shift from wetu telu dominance to wetu lima dominance had implications for the codification of kawin lari, as the kawin lari tradition has been modified to better reflect Islamic and State law since 2008 [8]-[12].

In Indonesian literature, the practice of kawin lari has often been viewed from a wetu lima or State perspective [13], [14]. Meanwhile, this article will examine Zohan Mayudi's novel Bisikan Tetesan Hujan, showing that it applies a rationalistic and modern perspective to understand the world [15]. Kawin lari, rather than being framed using romanticism [16], is constructed in the novel as a "trap", victimizing women. The practice of eloping in the novel Ketika Cinta Tak Mau Pergi does not succesfully achieve the unification. Sahnim does not have any powers to against the structure of nobility [16]. Meanwhile, in the novel Merpati Kembar di Lombok, the practice of eloping can unify Lale Erna and Suparman [13], [14]. Both of the novels put the practice of eloping in the dominance of nobility, meanwhile in the novel Bisikan Tetesan Hujan puts the practice of eloping in the context of society, jajar karang, not in the context of nobility.

\section{Research Method}

This article applies Stuart Hall's theory and methodology of representation, which relies on both semiotic and discursive approaches [17]. As representation implies the positioning of a practice within its cultural context, this article assumes that the cultural context of kawin lari is represented in the novel Bisikan Tetesan Hujan. This article thus used data from the novel as its primary data and discursive data as its secondary data. Primary data were collected by classifying sentences and paragraphs from the novel that discuss the practice of kawin lari. Secondary data, meanwhile, were collected through literary review. After the meaning of the text was identified through semiotic analysis, it was positioned within the context of kawin lari discourse in Lombok.

\section{Resulth And Discussion}

\subsection{Trapped by Tradition}

The novel Bisikan Tetesan Hujan deals with the Sasak tradition of kawin lari, popularly translated as elopement. In the novel, this tradition is practiced by Wawan Darmawan, who takes Salwa away from her house and marries her. Salwa does not love Wawan, but another man, Liwaul. Similarly, Liwaul loves Salwa, but has difficulty expressing his feelings.

"Liwa, you're the one." After she explained, the truth didn't sound too surprising. However, there was something hard to say, something that made them fall silent as they gazed into each other's eyes. "Say it again!", asked Liwa. Salwa softly brushed aside the fingers that were covering her face. By showing all of the beauty that the eyes could see, she was doing what Liwa had asked. "You're the one I've been waiting for!" [18, pp. 378-379]

Salwa explains that she has longed for Liwaul. However, Wawan Darmawan has already told her that he loves her. When Salwa learns that Liwaul loves her, she is unwilling to accept Wawan's proposal, stating that she is unready and that she desires to finish her studies. 
Wawan, however, is unwilling to accept this rejection, and chooses to practice the Sasak tradition of kawin lari. He steals Salwa away from her home.

Wawan couldn't understand. Fine then, Salwa thought. There were other words, clearer, but more hurtful. "I'm not ready. Really, really not ready. For marriage or for betrothal." Herman had been feeling ill at ease ever since Uncle Subki agreed to Wawan's final option: they would abduct Salwa. Tradition allowed them to steal away a girl, and indeed some parents who considered themselves firm adherents of Sasak culture would consider it an insult for someone to ask for their daughters' hand in marriage. Only things, possessions, could be requested; daughters were daughters, not objects. So, to do the honorable thing, and to be recognized as a daring young man, he had to abduct her, to steal her away from the watchful eyes of her family. He had to abduct her at night, because stealing a girl away during the day would leave him open to sanctions, to fines, the amount of which would be determined by the community [18, pp. 398-399].

As a result of Salwa's rejection, Wawan decides to rely on traditional means. Sasak tradition allows him to abduct and marry a woman. Parents are honored when their daughters are abducted. Similarly, a man's ability to abduct a woman is perceived as reflecting his strength, courage, and daring. Salwa's parents, however, are not firm adherents of tradition; they are educated, and thus oriented more towards modernity. Similarly, as civil servants they are more inclined to promote modernity over tradition. This is not to say that they reject the tradition of kawin lari; Salwa herself objects, as shown in her discussion of the matter with Wawan's brother Herman.

"Yeah, okay... but... what?"

"He wants to steal you away."

"What?" Without realizing it, Salwa had shouted. She immediately shut her mouth. Seeing that all heads had turned her way, she signaled to them that she was alright, that nothing had happened. "I don't want that." "I know. I know, you're not interested. So please, listen..."

"Okay. Tell me, how can I avoid away from this lunacy?"

"If someone asks you to come with them, anyone, except for your parents and your family... don't do it. He might try and get your friends involved, try to have them help. Try your best not to leave the house until you're back in Java." [18, p. 407]

This quote shows that Herman disagrees with Wawan's plan, and thus reveals it to Salwa. Salwa returns to Yogyakarta as quickly as she can. However, Wawan is still able to snare her, fabricating a story that he and Salwa had been intimate, and that Salwa has tried to hide her pregnancy by rushing back to Yogyakarta.

Wawan was lucky. He was able to convince Salwa's parents that they had agreed to get married, as time was short. Salwa's return to Yogyakarta, he said, was a sham; she just wanted to hide her pregnancy [18, p. 423].

Salwa's younger siblings tell her that her mother has fallen ill, and that she must return to Lombok quickly.

It became increasingly clear that Salwa had been tricked when she saw Wawan approaching. "Come on," he said. "The car's there."

Salwa looked at the car. "My father asked me to wait. He's grabbing a car." 
"That's the car. He asked me to pick you up."

"So, where's my father?"

"He met an old friend, over there." Wawan pointed to the crowd. "He said he'd join us later. Come on. Your mother can't wait to see you." [18, p. 433].

Wawan successfully deceives Salwa and her family. At the airport, Salwa is received by Wawan. At first, she refuses to join him. However, Wawan convinces her that he was acting on her father's instructions. Salwa marries Wawan, and thus begins her suffering.

\subsection{Salwa's Rebellion}

Over time, Salwa rebels. Her siblings help her escape from Wawan's home.

"Sis," said Ratna. "I've got a plan. I'm going to get a knife. After that, I'll tell you my plan.

"But where will we get the money?" Salwa asked after her sister explained her plan. "After I got married, I wasn't allowed to have any money."

"Don't worry," said Ratna. She came out with a kitchen knife. "I've got some money, enough for a bus ticket to Yogyakarta and to cover some expenses." Salwa wiped away her tears. As she attempted to regain control of herself, she held her hands out, allowing her sisters to remove the bonds from her wrists and ankles [18, p. 469].

Salwa is treated like a prisoner by her husband. Her hands are tied, and thus she cannot do anything. Concerned by Salwa's condition, they decide to help her escape and reunite with her beloved Liwaul.

"What time is it?" asked Salwa." Liwa showed her his watch. "One more hour."

"Are you sure you don't want to go with me?" Liwa had already explained, giving all sorts of academic reasons. He had many duties that he couldn't ignore, and he would be starting exams soon. There was another reason, something he couldn't say. Joining Salwa in her escape would mean losing his memories of her as she was before she married Wawan. He still loved her, in his heart. He would give her whatever she needed, but he couldn't let himself get carried away. There would be too much at stake if he forced himself to join Salwa on her journey. His parents would be disappointed. He was still in school, still doing his baccalaureate degree, and still relying on his family. All of his money was coming from his parents and his scholarship. If he ended up joining Salwa, they would surely decide that they needed to be married. As such, he would have to divide his time between his academic duties, his duties as a husband, and - maybe - his duties as the father of Guyana, a little girl he'd already named. [18, p. 486].

Salwa asks Liwa to live with her in Yogyakarta. Liwa, however, is unwilling to take the risk of leaving his studies and his family, thinking that he would be unable to bring joy to his parents if he were to do so. He decides to prioritize his family over his own desires. Furthermore, he seeks to preserve his honor; stealing another man's wife would be dishonorable. 


\subsection{Wawan and His Magic(al Realism)}

After Salwa leaves, Wawan decides to use magic to try and bring her back.

Wawan told the man of his problems, of everything that had happened after Salwa decided to run away. The mystic nodded along as he puffed on his cigarette. After Wawan finished saying everything he felt needed to be said, the mystic flicked his cigarette into an ashtray and focused. As the smoke from the butt floated up and covered his face, he childishly mixed the ashes as he nodded like a scientist ready to present his findings.

"She's in Mataram now."

"Is she near Dasan Agung?" Wawan wanted to know whether Salwa was with Sumiarni or... Oh, God... how could I be so stupid? He thought. He had just remembered. One of Liwa's friends had mentioned that his greatest rival lived there, in Dasan Agung. Was his wife with him? Finally, he asked one more thing. "Who's she with now?" The mystic wrinkled his brow, tightened up, then released his tension. "She's not in Dasan Agung. She looks like she's closer to Kekalik... wait... they're walking east now. She's walking with three people. Two men and a woman." Two men. Two men. Wawan was just about to ask whether the mystic was certain that there were two men, when he decided to focus on the men themselves. "What are they like, the men?"

"One seems to have been with her since leaving the house. Tall, thin, dark skin, and short hair."

"And the other?"

"Wavy hair, cut like an office boy's. His skin's a little lighter, and his eyelashes thicker. There's acne... a thin body, shorter than the other."

"Has he also been with her since leaving the house?" [18, pp. 478-479]

Salwa's decision to leave her home enrages her husband. Wawan seeks a mystic and asks him about her whereabouts. The mystic is able to locate her, saying that she is in Mataram, near Kekalik. He is also able to identify the people with whom Salwa is walking. He says that she is walking eastward together with three people, two men and a woman. The mystic is even able to describe these people in detail, as well as determine how long they have been together.

Wawan consults this mystic in order to locate his wife, Salwa. Indeed, he is almost able to bring her back.

"No, they just met."

"Could you tell me where they met?"

The mystic started sifting through his ashes again. "They met in a classroom. A big building, near the football field." On campus! Shit! Shit! I have to look for them there. Would it be safe for him, as an outsider, to start beating up that damned student who'd disturbed his household? The people on campus might defend Liwa, but husbands around the world would back him. There had to be a brotherhood of husbands. They needed that kind of support! Wawan wanted to head right over and deal with his problem, so he had to remind the mystic. "How can I make her do her duties as a wife?"

"There's no other way. You have to force her."

"But..." Wawan wasn't sure that he could tell the man in front of him that his wife was fitter than he was. "How?" [18, p. 480] 
Despite receiving such detailed information, Wawan arrives on campus too late to stop Salwa from leaving for Yogyakarta. The marriage between Wawan and Salwa ends in divorce, upon Salwa's insistence. Even with the help of a mystic, Wawan is unable to bring Salwa back; in other words, magic cannot force Salwa to return to her loveless marriage. In Indonesian literature, magical realism has frequently been used to support tradition [19], [20]. The tug-of-war between the real and the magical, between the rational Salwa and the superstitious Wawan, ends with the real emerging victorious.

\subsection{Realist Tendencies}

Salwa is able to escape her loveless marriage, and after her divorce she reunites with her beloved Liwaul.

Their first kiss was soft, warm, close, overwhelming. Liwa stepped forward, took Salwa's chin in his left hand, then let their lips become one, a union that could never be broken. When, after an eternity, they parted, Liwa saw that Salwa's eyes were still closed. Her soft breaths revealed her pleasure, her wish that the kiss had never ended. Afterwards, neither of them could look at the other. It was as though their passions had revealed their deepest secrets. They had to wait for a few minutes before they could speak - and listen. "Are you happy with me?", asked Liwa. Without that kiss, which still sent tremors throughout her body, she would have given the same answer. "Why do you think I ran, if not for the pleasure that I could find with you?" So many words crossed through her mind, before being replaced by a smile and a held gaze $[18$, p. 525].

Forced into marriage by the tradition of kawin lari, Salwa rebels and escapes from her loveless marriage. Desiring to be united with her beloved Liwa, and having saved her love and virginity for him, Salwa divorces her husband Wawan. Liwa and Salwa are able to become one. Their union represents the victory of the real world of modernity over the mystical and magical world of tradition. The practice of eloping in the novel Ketika Cinta Tak Mau Pergi tends to the persepctive of the ideal world, tradition, while in the novel Merpati Kembar di Lombok tends to the perspective of real world. The persepctive of real world in the novel Merpati Kembar di Lombok is presented in the context of nobility, while in the Bisikan Tetesan Hujan, it is presented in the context of modernity which can be seen by the involvement of country in solving the problem of Salwa and Wawan. The analysis result completes the previous findings about study of eloping in Indonesian literature.

\section{Conclusion}

In the novel Bisikan Tetesan Hujan, the Sasak tradition of kawin lari is presented as bringing nothing but suffering. Women are the victims of this tradition, being deceived by men and brought into undesirable situations. Specifically, this novel depicts a young man named Wawan as deceiving the parents of a young woman named Salwa, claiming that he had impregnated her and that she had fled to Yogyakarta. Only because of this lie do her parents agree to let Salwa be taken away. Salwa, however, does not desire marriage, and rebels against her husband. Escaping bondage, she abandons Wawan and reunites with her beloved. Wawan attempts to use magic(al realism) to bring Salwa back; however, he is ultimately unsuccessful, 
being defeated by modern concepts of individual freedom and women's rights. As a divorcee, Salwa reunites with her beloved Liwaul.

\section{Acknowledgment}

This article is part of my dissertation; therefore, I would like to express my great gratitude to the Directorate of Research and Community Service, Directorate General of Strengthening for Research and Development, the Ministry of Research, Technology and Higher Education who has funded this dissertation research.

\section{References}

[1] A. May, Y. Ali, Mahrip, Winangun, Yah, and M. M. Duliun, Tata Kelakukan di Lingkungan Pergaulan Keluarga dan Masyarakat Nusa Tenggara Barat. Jakarta: Departemen Pendidikan dan Kebudayaan, 1989.

[2] Tim Penyusun, Adat Istiadat Daerah Nusa Tenggara Barat. Jakarta: Departemen Pendidikan dan Kebudayaan, 1977.

[3] R. Krulfeld, "Fatalism in Indonesia : A Comparison of Socio-Religious Types on Lombok," Anthropol. Q., vol. 39, no. 3, pp. 180-190, 1966.

[4] A. van der Kraan, Lombok: Penaklukkan, Penjajahan dan Keterbelakangan 1870-1940, Terj. 2009. Mataram: Lengge, 1981.

[5] J. L. Ecklund, "Sasak Cultural Change , Ritual Change , and the Use of Ritualized Language," Indonesia, vol. 24, no. 24, pp. 1-25, 1977.

[6] J. M. MacDougall, "Buddhist Buda or Buda Buddhists?: Coversion, Rwligious Modernism and Conflict in the Minority Buda Sasak Communties of New Order and Post-SUgarto Lombok," Princeton University, 2005.

[7] J. Ryan, "Alif Lam Mim: Reconciling Islam, Modernity, and Tradistion in an Indonesian Kampung," Harvard University, 1999.

[8] N. Yasin, Hukum Perkawinan Islam Sasak. Malang: UIN Malang Press, 2008

[9] W. Lukman, "Eksistensi Perkawinan Masyarakat Suku Sasak Lombok (Merariq) Dalam Muara Pluralisme Hukum,” IUS Vol.II No. 6 Desember, vol. II, pp. 427-444, 2014.

[10] Basriadi, "Tinjauan Hukum Islam terhadap Perkawinan Beda Kelas Muslim Sasak di Lombok,” Maraji J. Stud. Keislam., vol. 1, no. 2, pp. 297-329, 2015.

[11] M. N. Aminullah, "Akulturasi Islam dengan TRadisi Perkawinan Masyarakat Bangsawan Sasak (Studi di Kecamatan Kopang Kabupaten Lombok Tengah,” Palapa J. Stud. Keislam., vol. 5, no. 1, pp. 109-137, 2017.

[12] I. R. Mahayanti, "Pemberian Pisuke dalam Perkawinan Adat Masyarakat Sasak di Desa Dasan Tereng Kec. Narmada Kabupaten Lombok Barat,” Unversitas Gadjah Mada, 2017.

[13] H. Wijaya, "Merpati Kembar di Lombok karya Nuriadi (Kajian Sosiologi Sastra, Budaya, Resepsi, dan Nilai Pendidikan)," Universitas Sebelas Maret, 2013.

[14] S. Zuhairini, "Idealisme Perjuangan Perempuan Sasak dalam Novel "Merpati Kembar di Lombok' karya Nuriadi dan Relevansinya terhadap Pembelajaran Sastra di SMAN 1 Kediri," Mabasindo, vol. 1, no. 1, pp. 75-84, 2017.

[15] Faruk, Beyond Iamagination, Sastra Mutakhir dan Ideologi. Yogyakarta: Gama Media, 2001.

[16] D. Satrya HD, "Feudalism versus Capitalism: The Changing Representation of Lombok in Nadira Khalid's Novel Ketika Cinta Tak Mau Pergi," 3 L Lang. Linguist. Lit., vol. 24, no. 4, pp. $115-127,2018$.

[17] S. Hall, "The Work of Representation," in Representation: Cultural Representations and Signifying Practices, S. Hall, Ed. London: Sage Publication, 1997, pp. 1-74. 
[18] J. Mahyudi, Bisikan Tetesan Hujan. Mataram: Arga Puji Press, 2012.

[19] A. Shahab, "Kontestasi Paradigma Antara Mitos dan Logos di dalam Novel: Sebuah Proses Transkulturasi dan Dialog Kebudayaan Analisis Magical Realism atas Les yeux baissés Karya Tahar Ben Jelloun," Universitas Gadjah Mada, 2014.

[20] D. Satrya HD, "Realisme Magis di Indonesia: Studi Kasus pada Novel Babad Syaikh Siti Jenar," Universitas Gadjah Mada, 2014. 